\title{
Disentangling the Effects of Genotype and Environment on Growth and Wood Features of Balfourodendron riedelianum Trees by Common Garden Experiments in Brazil
}

\author{
Jane Rodrigues da Silva ${ }^{1, * \mathbb{D}}$, Sergio Rossi ${ }^{2}$, Siddhartha Khare ${ }^{2, * \mathbb{D}}$, Eduardo Luiz Longui ${ }^{3}$ and \\ Carmen Regina Marcati ${ }^{1}$ (D) \\ 1 Laboratório de Anatomia da Madeira, Departamento de Ciência Florestal, Solos e Ambiente, \\ Faculdade de Ciências Agronômicas, Universidade Estadual Paulista (UNESP), Câmpus de Botucatu, \\ Botucatu, SP 18610-034, Brazil; carmen.marcati@unesp.br \\ 2 Département des Sciences Fondamentales, Université du Quebec à Chicoutimi, \\ Chicoutimi, QC G7H 2B1, Canada; Sergio_Rossi@uqac.ca \\ 3 Instituto Florestal, São Paulo 02377-000, Brazil; edulongui@gmail.com \\ * Correspondence: janersbio@gmail.com (J.R.d.S.); siddhartha.khare@gmail.com (S.K.)
}

Received: 21 July 2020; Accepted: 17 August 2020; Published: 19 August 2020

check for updates

\begin{abstract}
Intraspecific studies with populations replicated in different sites allow the effects of genotype and environment on wood features and plant growth to be distinguished. Based on climate change predictions, this distinction is important for establishing future patterns in the distribution of tree species. We quantified the effects of genotype and environment on wood features and growth of 30-year-old Balfourodendron riedelianum trees. We used three provenances planted in two common garden experiments with difference in precipitation and temperature. We applied linear models to estimate the variability in wood and growth features and transfer functions to evaluate the responses of these features to temperature, precipitation, and the standardized precipitation evapotranspiration index (SPEI). Our results showed that genotype had an effect on vessels and rays, where narrower vessels with thinner walls and larger intervessel pits, and shorter, narrower and more numerous rays were observed in provenances from drier sites. We also observed the effect of the environment on wood features and growth. Trees growing in the wetter site were taller and larger, and they had wider vessels with thicker walls and lower ray density. Transfer functions indicated that an increase in temperature results in larger vessels with thicker walls, taller and denser rays, shorter and narrower fibers with thinner walls, and lower wood density. From a functional perspective, these features make trees growing in warmer environments more prone to drought-induced embolisms and more vulnerable to mechanical damage and pathogen attacks. Tree growth varied with precipitation and SPEI, being negatively affected in the drier site. Overall, we demonstrated that both genotype and environment affect wood features, while tree growth is mainly influenced by the environment. Plastic responses in hydraulic characteristics could represent important functional traits to mitigate the consequences of ongoing climate change on the growth and survival of the species within its natural range.
\end{abstract}

Keywords: drought; phenotypic plasticity; provenance test; common garden; transfer functions

\section{Introduction}

The effect of environmental variability on the wood features in long-lived plants has been studied for almost a century. These studies allowed establishment of the main ecological trends in wood 
anatomical features of woody plant populations grown in sites with different water availability, showing the effects of local conditions (e.g., precipitation, temperature, and soil physical properties) on their anatomical structure. However, besides the environmental conditions of the growing site, the wood features still remain under strong genetic control [1], making it a challenge to determine which anatomical features are determined by genotype, induced by environmental variability, or resulting from an interaction of these two factors [2].

Common garden experiments with different seed sources replicated in environments with variable water availability has proven to be a useful tool in disentangling the genetic from environmental effects on wood features in tree species with wide distributions [3,4]. For example, common garden experiments performed by Fisher et al. [5] and Schreiber et al. [6] showed that the place of origin of plants is an important selection factor for vessel diameter variability. In general, populations coming from places prone to cold or drought tend to have narrower vessels as a result of high selective pressures under water stress environments [1,7]. Instead, the responses of hydraulic traits to changes in environmental plant growth conditions varied among populations. In some of them, vessel diameters were sensitive to increased water availability, producing slightly wider vessels and consequently increasing water transport efficiency, with positive effects on plant growth and survival. However, in some populations, the genotype may buffer the effects of environmental variability on wood formation, demonstrating that the interaction between genotype and environment in determining their anatomical features is more complex than expected. The effects of the genotype and the environment are also observed in plant growth. In general, trees from drier sites are generally smaller than trees from wetter sites, according to a well-known positive effect of precipitation on growth $[8,9]$.

Another important factor that should be considered in relation to the responses of wood to environmental variability is the involvement of cells in simultaneous multiple functions [10,11]. The numerous possibilities of arrangement, as well as the diverse interactions between the different cell types (water-conducting cells, fibers, and axial parenchyma and rays), have allowed long-lived plants to develop different strategies that ensure their growth and survival in periods of water stress. For example, in drier environments, to minimize hydraulic failures and avoid vessel collapse due to higher water flow stresses, narrower vessels are formed, with thicker cell walls [12,13], denser [12,13], more clustered [13,14], with smaller intervessel pits [15]. The narrowing of vessel diameter, associated with the thickening of cell walls, may confer greater safety to water transport, increasing the mechanical resistance of vessel walls to implosion [16]. Higher vessel density increases the possibility of water flow pathways in the case of embolism [17] at the same time as it increases the water conductive area [18]. Vessels in larger groupings provide greater connectivity between them, offering alternative pathways to water flow in cases of embolisms, which could keep the water column functional without substantial reduction in water transport [18].

Adaptation of the wood experiencing changes in water availability also involves adjustments between vessels, parenchyma cells (axial parenchyma and rays) and fibers. In a global approach, Morris et al. [19] showed that there is a positive correlation between vessel diameter and the amount of axial parenchyma in warmer sites. In these conditions, the interaction between parenchymal cells and vessels may act as an ancillary mechanism for greater water transport safety during periods of water stress, increasing the possibility of water refilling in embolized vessels [20] and water storage capacity in the stem [21]. Another possibility of wood construction to minimize the effects of water stress is through the interaction between vessels and fibers. Wood composed of a fiber matrix with thick walls in dry environments could provide greater mechanical support to the vessels and thus reduce the risks of vessel implosion in case of higher negative pressure $[10,16]$. The formation of a dense matrix of thick-walled fibers can also lead to an increase in the mechanical strength of the stem with a positive effect on wood density, while decreasing water conduction and storage capacity in the stem, reducing plant growth [22]. In addition, a dense fiber network could compensate for weaker areas of wood composed of large or denser vessels [16]. Such evidence shows that wood anatomical variations are related to the integrated changes between its different cell types to adjust 
to environmental variability [23], which could minimize, through different pathways, the effects of environmental variation on hydraulic traits. Thus, it is clear that detailed analyses of wood and its responses to drought events are essential for a detailed assessment of plants potential to withstand ongoing climate change. However, so far, little is known about the intraspecific variation and interaction between the cellular types of wood, as well as the effect of genotype and environment on these cells, in tree species with wide geographic distribution.

Under the current scenarios of changes in the seasonality of rainfall and warming [24], knowing which wood features are determined by genotype and which are more plastic will be essential to indicate the impacts of climate change on xylem formation. Furthermore, knowing the plastic responses of the hydraulic system and its effects on plant growth will contribute to improve the strategies of assisted migration of tree species from and towards forest sites worldwide, especially in neotropical forests. We therefore investigated the intraspecific variation in wood features and tree growth, estimated by stem height and diameter, in 30-year-old trees from three populations of Balfourodendron riedelianum (Engl.) Engl. (Rutaceae) grown in two common garden experiments as provenance tests. B. riedelianum is a long-lived and slow growing deciduous species reaching up to $32 \mathrm{~m}$ in height, with stems reaching $80 \mathrm{~cm}$ in diameter. Native of semideciduous seasonal forests, this species has a wide geographical distribution in Neotropical seasonally dry forests of Brazil, Argentina, and Paraguay [25]. In this study, we evaluated the effect of climate at the origin sites on wood features and tree growth through transfer functions. The following hypotheses were tested: (i) trees originating from drier sites exhibit lower growth and produce wood with higher hydraulic safety; (ii) trees planted in trial sites with greater water availability exhibit higher stem growth and wood with large vessels regardless of their origin.

\section{Materials and Methods}

\subsection{Study Species, Common Gardens, and Sampling}

This study was carried out in two common gardens with 30-year-old B. riedelianum trees located in Luís Antônio (LA; $21^{\circ} 40^{\prime}$ S, $47^{\circ} 49^{\prime} \mathrm{W}$ ) and Pederneiras (PE; 22 $21^{\prime} \mathrm{S}, 48^{\circ} 46^{\prime} \mathrm{W}$ ), São Paulo State, Brazil. Both sites are at an altitude of $500 \mathrm{~m}$ and have a dry season from May to September (rainfall $\leq 50 \mathrm{~mm}$ ), as well as a hot and rainy season from November to March. The annual precipitation, mean annual temperature, summer mean temperature and winter mean temperature are described in Table 1. The soils differ between sites: dark red latosol with clay texture in LA [26] and sandy yellow latosol in PE [27].

The common gardens originated from seeds collected in three natural populations of B. riedelianum, Alvorada do Sul (AS), in the State of Paraná, Bauru (BA) and Gália (GA), both in the State of São Paulo (Table 1). The seeds in AS were collected in the semideciduous seasonal forest. The seeds in BA were collected at the ecotone between the semideciduous seasonal forest and Cerrado. The seeds in GA were collected in the semideciduous seasonal forest. 
Table 1. Site characteristics at the trial sites and provenance origin

\begin{tabular}{|c|c|c|c|}
\hline & \multicolumn{3}{|c|}{ Trial Sites } \\
\hline & \multicolumn{2}{|c|}{ Luís Antônio (LA) } & Pederneiras (PE) \\
\hline Mean annual precipitation & \multicolumn{2}{|c|}{$1340 \mathrm{~mm}$} & $1260 \mathrm{~mm}$ \\
\hline Mean annual temperature & \multicolumn{2}{|c|}{$23.5^{\circ} \mathrm{C}$} & $22.6^{\circ} \mathrm{C}$ \\
\hline Summer (December-February) mean temperature & \multicolumn{2}{|c|}{$31.4{ }^{\circ} \mathrm{C}$} & $34.3^{\circ} \mathrm{C}$ \\
\hline \multirow[t]{4}{*}{ Winter (June-August) mean temperature } & \multicolumn{2}{|c|}{$11.9^{\circ} \mathrm{C}$} & $14.0^{\circ} \mathrm{C}$ \\
\hline & \multicolumn{3}{|c|}{ Provenances } \\
\hline & Alvorada do Sul (AS) & Bauru (BA) & Gália (GA) \\
\hline & $22^{\circ} 46^{\prime} 49^{\prime \prime} \mathrm{S}, 51^{\circ} 13^{\prime} 52^{\prime \prime} \mathrm{W}$ & $22^{\circ} 18^{\prime} 53^{\prime \prime} \mathrm{S}, 49^{\circ} 03^{\prime} 38^{\prime \prime} \mathrm{W}$ & $22^{\circ} 17^{\prime} 29^{\prime \prime} \mathrm{S}, 49^{\circ} 33^{\prime} 10^{\prime \prime} \mathrm{W}$ \\
\hline Mean annual precipitation* & $1.368 \mathrm{~mm}$ & $1.296 \mathrm{~mm}$ & $1.395 \mathrm{~mm}$ \\
\hline Mean annual temperature* & $22.1^{\circ} \mathrm{C}$ & $22.5^{\circ} \mathrm{C}$ & $22.0^{\circ} \mathrm{C}$ \\
\hline Altitude & $320 \mathrm{~m}$ a.s.l & $530 \mathrm{~m}$ a.s.l & $650 \mathrm{~m}$ a.s.l \\
\hline Soil type and features ** & $\begin{array}{l}\text { Red Nitosol, clayey to very clayey texture, } \\
\text { deep, high water holding capacity, well } \\
\text { drained, moderately acidic, medium to high } \\
\text { natural fertility. }\end{array}$ & $\begin{array}{l}\text { Red Argisols, medium to coarse texture close } \\
\text { to sandy, deep, low water holding capacity, } \\
\text { low natural fertility. }\end{array}$ & $\begin{array}{l}\text { Dystrophic Red-Yellow Latosol; medium } \\
\text { texture (15-25\% clay); deep, low water } \\
\text { holding capacity; low natural fertility, }\end{array}$ \\
\hline
\end{tabular}

* Data obtained from Sistema de Informação Hidrológicas /Agência Nacional de Águas (ANA) (http://hidroweb.ana.gov.br). Mean annual precipitation and mean annual temperature data from January 1975 to December 1985. ** Data obtained from Bhering et al. [28] to the municipality of Alvorada do Sul/PR, from the Plano de Manejo da Estação Ecológica de Bauru to the municipality of Bauru/SP e de ESALQ-USP [29] to the municipality of Gália/SP. 
Both common gardens were established in 1985 using seedlings of B. riedelianum from open-pollinated seeds collected from 19 maternal trees per populations (AS, BA, and GA), and involving provenance and progeny trials [30]. Provenance refers to the place of origin of populations and progeny denotes individuals that share maternal genetic material (half-siblings). The common gardens were arranged as randomized complete blocks designed with six replications per provenance. Each block was divided into three plots, with one provenance per plot, and progeny allocated in sub-plots. In each row of the sub-plots, five seedlings of the same progeny were planted at a spacing of $3 \mathrm{~m} \times 3 \mathrm{~m}$, with two external border rows of the same species. We measured stem height and diameter at breast height, and collected wood samples from the main stem at $1.30 \mathrm{~m}$ above the ground from 36 trees for each common garden (12 trees per provenance). From each provenance, we selected three random progenies (AS, BA, and GA) and four random trees per progeny within the sub-plots. We collected trees of the same progeny in both trial sites.

\subsection{Wood Anatomical Procedures}

We collected one $10 \mathrm{~cm}$ disc from the main stem at $1.30 \mathrm{~m}$ above the ground per sampled tree. From each disc, we removed wood samples with approximately $3 \mathrm{~cm}^{3}$ containing the sapwood nearest to the bark for wood-anatomical, scanning electron microscopy, and wood density analysis.

For anatomical analysis, we fixed wood samples in $\mathrm{FAA}_{50}$ (formaldehyde, acetic acid, ethanol $50 \%$ 1:1:18) for $48 \mathrm{~h}$ and then transferred them to $70 \%$ ethanol [31] for storage. We performed histological sections using a sliding microtome on the radial longitudinal, tangential longitudinal, and cross directions. The thickness of the histological sections varied from 12 to $15 \mu \mathrm{m}$. Sections were stained with $1 \%$ aqueous of safranin [32] and 1\% aqueous of astra blue [33] and mounted on permanent slides with Entellan ${ }^{\circledR}$ synthetic resin. For maceration, we followed the Franklin method [34] modified by Kraus and Arduin [35]. We put small portions of the wood samples in a solution of glacial acetic acid and hydrogen peroxide $(1: 1 \mathrm{v:v})$ at $60^{\circ} \mathrm{C}$ for $24 \mathrm{~h}$, washed in water, stained with aqueous $1 \%$ safranin, and mounted semi-permanent slides in a glycerin and water solution (1:1 v:v). We analyzed the wood anatomy slides under a light microscope equipped with an AxioCAM MRC and Axiovision software. We used the recommendations of the International Association of Wood Anatomists Committee [36] for wood anatomical description.

\subsection{Wood Data Collection}

We measured wood anatomical features, including vessel density, vessel wall thickness, vessel element length; height and width of rays and numbers of rays per linear $\mathrm{mm}$; and length, diameter, and lumen thickness of fibers. We performed 30 measurements for each wood anatomical features per sampled tree. We used images with 300 dpi resolution. To determine the vessel density, we counted the number of vessels in 30 areas of $1 \mathrm{~mm}^{2}$ in transverse section per tree sampled. We calculated the fiber wall thickness $(F w t)$ by the following formula:

$$
F w t=\frac{(F d-d)}{2}
$$

where $(F d)=$ total fiber diameter, and $(d)=$ fiber lumen diameter.

We estimated vessel, fiber and parenchyma (rays + axial parenchyma) fractions (\%) in the wood. We used 15 areas of $1 \mathrm{~mm}^{2}$ in transverse sections images per tree. To assess the fraction (\%) of area occupied by the parenchyma, we calculated by subtracting the area of fibers and vessels from total measured wood area. We performed all wood anatomical linear and area measurements using ImageJ 1.6.0 (https://imagej.nih.gov/ij/download.html; National Institutes of Health, Bethesda, MD, USA).

Since vessels are not exactly circular as seen in the transverse section, we calculated vessel diameter $(D v)$ of each vessel based on the vessel lumen area [37]. We calculated the vessel diameter as: 


$$
D v=\frac{\sqrt{4 A}}{\pi}
$$

where $A$ is the vessel lumen area. The vessel lumen area was measured from 50 vessels per tree.

We calculated the potential hydraulic conductivity $(K p)$ following the Hagen-Poiseuille law [22].

$$
K p=\left(\frac{\pi \rho w}{128 n}\right) \cdot V D \cdot D h^{4},
$$

where $\mathrm{K} p$ is the potential hydraulic conductivity (in $\mathrm{Kg} \mathrm{m}^{-1} \mathrm{MPa}^{-1} \mathrm{~s}^{-1}$ ), $\rho w$ is the density of water at $20^{\circ} \mathrm{C}\left(998.2 \mathrm{~kg} \mathrm{~m}^{-3}\right.$ at $\left.20^{\circ} \mathrm{C}\right), n$ is the viscosity of water at $20^{\circ} \mathrm{C}\left(1.00210^{-3} \mathrm{~Pa}\right.$ s at $\left.20^{\circ} \mathrm{C}\right), V D$ is the vessel density $\left(\mathrm{n}^{\circ}\right.$ vessels $\mathrm{mm}^{-2}$ ), and $D h$ is the hydraulically weighted vessel diameter (in $\mathrm{m}$ ). The hydraulically weighted vessel diameter was calculated using the following formula:

$$
D h=\left(\frac{\sum d^{4}}{(N)^{0.25}}\right)
$$

where $d$ is the vessel diameter (in $\mu \mathrm{m}$ ), and $N$ is the number of vessels. The $D h$ represents the mean diameter that all vessels in stem would have in order to correspond to the same total conductivity for the same numbers of vessels [37,38].

In addition, we calculated the vessel grouping index as the total number of vessels divided by the total number of vessel groupings [37,39]. We selected 25 vessel groups and counted the total number of vessels in these groups and then divided the total number of vessel groups by 25 . Both solitary vessels and grouped vessels were counted as vessel groups.

\subsection{Scanning Electron Microscopy}

We measured the intervessel pit area and intervessel pit aperture area on images taken with a scanning electron microscope. We selected three trees of each population (AS, BA, and GA) in each common garden (LA and PE). Wood samples fixed in $\mathrm{FAA}_{50}$ with $2 \mathrm{~mm}$ lengths were split in a tangential plane, dehydrated in ethanol series from 50 to $100 \%$, and then air dried for $24 \mathrm{~h}$. The split wood samples were fixed to stubs with an electron-conductive carbon sticker, gold-coated with a sputter coater (Baltec SCD 050) for $3 \mathrm{~min}$. We observed the intervessel pits with a scanning electron microscope at an accelerating voltage of $15 \mathrm{kV}$. The intervessel pit area and intervessel pit aperture were measured from 50 vessels per tree using ImageJ 1.6.0 (https://imagej.nih.gov/ij/download.html; National Institutes of Health, Bethesda, MD, USA).

\subsection{Wood Density}

We used the water displacement method to assess wood density (in $\mathrm{g} \mathrm{cm}^{-3}$ ), corresponding to the wood dry mass over wood fresh volume [40]. Fresh volume of wood was estimated by immersion in water. We considered the weight of the displaced water equal to the volume of the sample $\left(1 \mathrm{~g}=1 \mathrm{~cm}^{3}\right)$. The wood samples were then dried at $105^{\circ} \mathrm{C}$ for $72 \mathrm{~h}$ and weighed to measure dry mass.

\subsection{Statistics and Transfer Functions}

Multivariate analysis of variance (MANOVA) was performed based on the measurements collected on the 72 study trees, involving tree height, and diameter and wood features. The three provenance origins and two common gardens, as well as their interaction, were included as independent factors. Post-hoc tests based on contrasts were used to verify differences within each factor. We performed univariate analyses using mixed models by testing for differences between provenance origin, common gardens, and progenies using tree as a random factor. The factor progeny was nested in the provenance origin. 
We extracted monthly temperatures and precipitations at the provenance origins and trial sites for a period covering 30 years (1970-2000) from the climatic datasets in WorldClim 2 [41]. Standardized precipitation evapotranspiration index (SPEI) [42] was calculated using SPEI package [43] in R software, version 1.2.5033 (R Foundation for Statistical Computing, Vienna, Austria) [44]. We performed Principal Component Analysis (PCA) to describe the climatic distance between sites based on the 19 bioclimatic parameters proposed by O'Donnell and Ignizio [45]. We identified the bioclimatic parameters with the stronger impact on the principal components based on Pearson's correlation coefficients. Response to climate shift was calculated using linear regressions as a function of the climate transfer difference, i.e., difference in temperature, precipitation, and SPEI between the provenance origin and trial sites. Unless otherwise specified, the statistics were performed in SAS 9.4 (SAS Institute Inc., Cary, NC, USA).

\section{Results}

\subsection{Variation in Wood Features and Growth}

MANOVA confirmed the effect of provenance (Wilks' $\lambda=0.01, \mathrm{~F}=15.51, p<0.0001$ ), trial sites (Wilks' $\lambda=0.06, F=34.86, p<0.001$ ), and their interaction (Wilks' $\lambda=0.21, \mathrm{~F}=2.95, p<0.0001$ ) on the multivariate dataset, including stem height and diameter and wood features. In addition, the analysis of variance showed differences between the two common gardens $\left(\mathrm{LA} \times \mathrm{PE}, \mathrm{Wilks}^{\prime} \lambda=0.20, \mathrm{~F}=9.82\right.$, $p<0.001$ ) and provenance origins (AS $\times \mathrm{BA} \mathrm{Wilks}^{\prime} \lambda=0.20, \mathrm{~F}=9.82, p<0.001 ; \mathrm{AS} \times \mathrm{GA} \mathrm{Wilks}^{\prime} \lambda=0.10$, $\mathrm{F}=20.64, p<0.001 ; \mathrm{BA} \times \mathrm{GA}_{\mathrm{Wilks}}{ }^{\lambda}=0.05, \mathrm{~F}=45.94, p<0.001$; Figure 1).

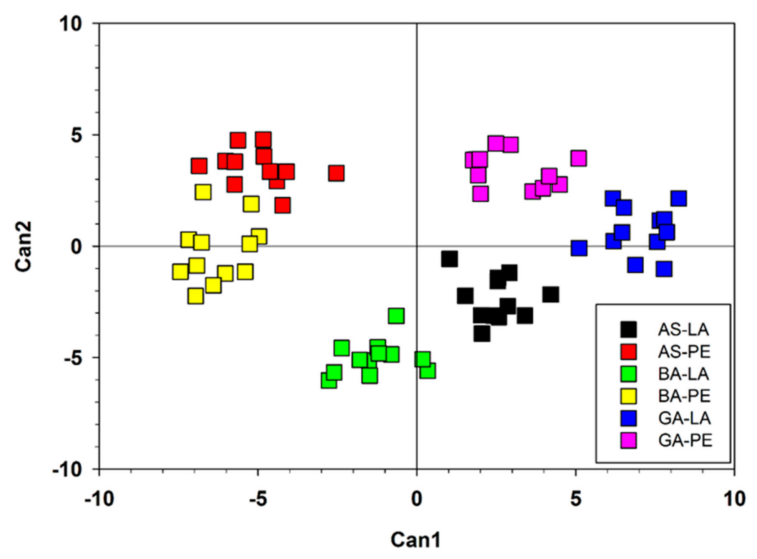

Figure 1. Graphic representation of the multivariate analysis of variance (MANOVA) multivar showing the separation between provenances (Alvorada do Sul (AS), Bauru (BA), and Gália (GA)) of Balfourodendron riedelianum trees grown in two common garden experiments (Luís Antônio (LA) and Pederneiras (PE)).

Stem height and diameter differed only between trial sites, where trees in LA trial site were taller and larger than those in PE trial site (Figure 2). In relation to trial sites, differences were observed in the following wood features: potential hydraulic conductivity, vessel diameter, vessel wall thickness, vessel element length, vessel grouping index, intervessel pit area, intervessel pit aperture area, fiber lumen diameter, fiber wall thickness, ray density, and parenchyma fraction. In general, trees in LA trial site had sparser and wider vessels(Figure 3), thicker walls, longer vessel elements, larger intervessel pits, fibers with thicker wall and larger lumen, lower ray density, lower parenchyma fraction, and higher potential hydraulic conductivity than in PE trial site (Figure 4; Table 2; Supplementary Table S1). Wood density, vessel density, fiber length and diameter, ray height and width, vessel fraction, and fiber fraction did not differ significantly between the trial sites. Differences between provenances were observed for potential hydraulic conductivity, vessel diameter, vessel wall thickness, vessel density, vessel grouping index, intervessel pit area, intervessel pit aperture area, ray height, ray width, ray density, vessel fraction, fiber fraction, and parenchyma fraction. 


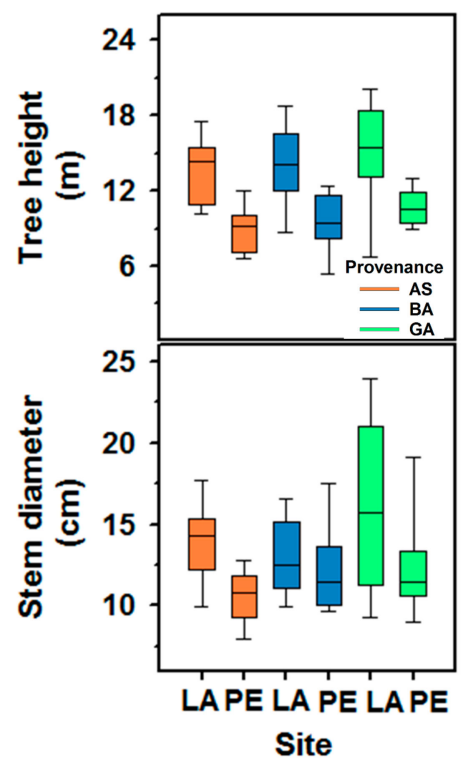

Figure 2. Boxplots showing stem growth features of 30-year-old trees from three provenances (AS, $\mathrm{BA}$, and GA) of Balfourodendron riedelianum grown in two common garden experiments (LA and PE). The stem height and diameter differ between the trial sites (stem height: site $p=<0.0001$; provenance $p=0.16$; stem diameter: site $p=0.003$; provenance $p=0.06$ ).

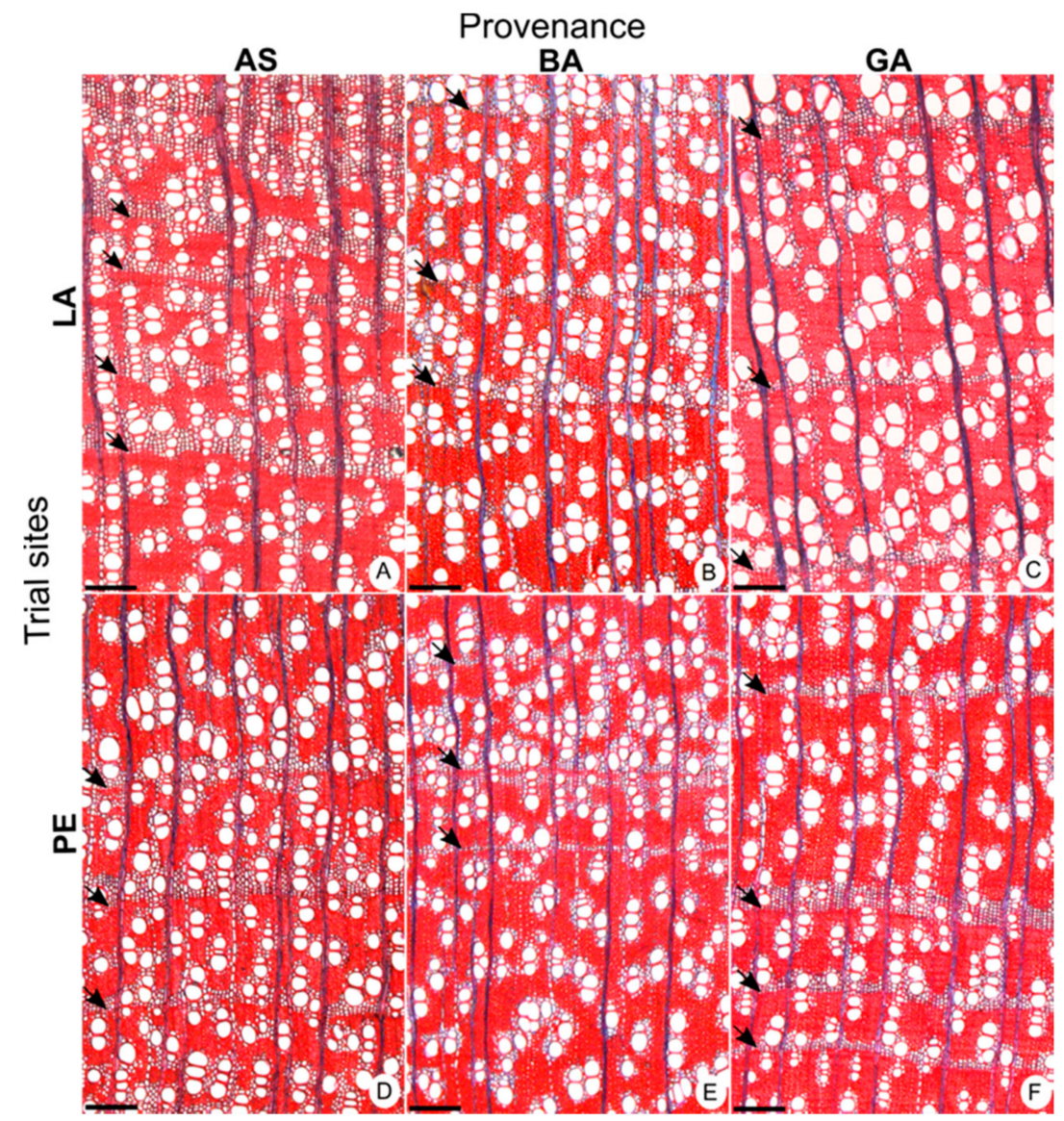

Figure 3. Wood cross-sections of Balfourodendron riedelianum trees. Trees grown in the Luís Antônio (A-C) and Pederneiras (D-F) trial sites. (A,D) Trees from Alvorada do Sul (AS), (B,E) from Bauru (BA), and $(\mathbf{C}, \mathbf{F})$ from Gália (GA) provenances. The arrows indicate the growth ring demarcated by marginal parenchyma bands. Scale bars: $(\mathbf{A}-\mathbf{F})=100 \mu \mathrm{m}$. 



Figure 4. Boxplots showing wood features of 30-year-old Balfourodendron riedelianum trees from three provenances (AS, BA, and GA) grown in two common garden experiments (LA and PE). 
Table 2. Results of the mixed models used to test the difference between trial site, provenance, and progeny on wood features and growth of 30-year-old Balfourodendron riedelianum trees.

\begin{tabular}{|c|c|c|c|c|c|c|c|c|c|c|}
\hline & \multicolumn{2}{|c|}{ Site } & \multicolumn{2}{|c|}{ Provenance } & \multicolumn{2}{|c|}{ Provenance $\times$ site } & \multicolumn{2}{|c|}{ Progeny } & \multicolumn{2}{|c|}{ Site $\times$ Progeny } \\
\hline & F-Value & $p$ & F-Value & $p$ & F-Value & $p$ & F-Value & $p$ & F-Value & $p$ \\
\hline Stem height & 49.19 & $<0.0001$ & 1.90 & 0.16 & 0.06 & 0.94 & 0.74 & 0.62 & 0.80 & 0.58 \\
\hline Stem diameter at breast height & 12.26 & 0.003 & 2.87 & 0.06 & 1.42 & 0.27 & 1.70 & 0.14 & 0.37 & 0.88 \\
\hline Wood density & 0.42 & 0.52 & 1.85 & 0.17 & 1.41 & 0.27 & 0.57 & 0.75 & 1.23 & 0.34 \\
\hline Potential hydraulic conductivity & 14.96 & 0.0014 & 32.60 & $<0.001$ & 8.78 & 0.0027 & 0.90 & 0.50 & 2.45 & 0.07 \\
\hline Vessel diameter & 218.32 & $<0.001$ & 208.3 & $<0.001$ & 0.28 & 0.75 & 3.28 & 0.01 & 3.16 & 0.03 \\
\hline Vessel wall thickness & 4.84 & 0.04 & 323.05 & $<0.001$ & 0.65 & 0.53 & 3.74 & 0.005 & 3.82 & 0.01 \\
\hline Vessel density & 0.71 & 0.41 & 17.30 & $<0.001$ & 3.94 & 0.04 & 1.45 & 0.22 & 1.40 & 0.27 \\
\hline Vessel element length & 27.98 & $<0.0001$ & 0.02 & 0.98 & 1.21 & 0.32 & 4.27 & 0.002 & 1.06 & 0.42 \\
\hline Vessel grouping index & 5.79 & 0.02 & 19.47 & $<0.0001$ & 2.75 & 0.09 & 0.78 & 0.58 & 2.10 & 0.11 \\
\hline Intervessel pit area & 13.44 & 0.0032 & 5.77 & 0.01 & 3.89 & 0.04 & - & - & - & - \\
\hline Intervessel pit aperture area & 9.62 & 0.0092 & 11.39 & 0.001 & 0.23 & 0.79 & - & - & - & - \\
\hline Fiber length & 1.15 & 0.29 & 2.73 & 0.07 & 1.81 & 0.19 & 0.67 & 0.67 & 2.16 & 0.10 \\
\hline Fiber diameter & 0.22 & 0.64 & 2.70 & 0.07 & 0.38 & 0.68 & 1.52 & 0.19 & 1.86 & 0.15 \\
\hline Fiber lumen diameter & 25.30 & 0.0001 & 1.42 & 0.25 & 6.79 & 0.007 & 0.94 & 0.48 & 1.12 & 0.39 \\
\hline Fiber wall thickness & 5.10 & 0.03 & 2.15 & 0.13 & 4.28 & 0.03 & 0.24 & 0.98 & 1.20 & 0.35 \\
\hline Ray height & 2.46 & 0.13 & 7.93 & 0.001 & 0.20 & 0.82 & 0.84 & 0.54 & 1.45 & 0.25 \\
\hline Ray width & 0.08 & 0.78 & 4.95 & 0.01 & 0.48 & 0.62 & 2.45 & 0.04 & 2.41 & 0.07 \\
\hline Ray density & 91.38 & $<0.001$ & 10.41 & 0.0002 & 2.25 & 0.13 & 0.66 & 0.68 & 0.95 & 0.48 \\
\hline Vessel fraction & 3.56 & 0.07 & 3.82 & 0.03 & 1.94 & 0.17 & 0.94 & 0.47 & 1.86 & 0.15 \\
\hline Fiber fraction & 0.12 & 0.73 & 3.64 & 0.03 & 1.28 & 0.30 & 0.96 & 0.46 & 1.42 & 0.26 \\
\hline Parenchyma fraction & 7.88 & 0.01 & 4.41 & 0.01 & 0.49 & 0.62 & 0.67 & 0.67 & 1.41 & 0.27 \\
\hline
\end{tabular}


In general, the trees from GA had larger vessels (Figure 3) with thicker walls, less dense and clustered, and with larger intervessel pits, taller and wider and lower density rays, smaller vessel and parenchyma fraction, and larger fiber fraction, plus higher potential hydraulic conductivity than the trees from AS and BA (Figure 4; Table 2; Supplementary Table S1).

The analyses showed that vessel diameter, vessel wall thickness, vessel element length, and ray width differed between progenies. There was an interaction trial site $\times$ provenance in the potential hydraulic conductivity, vessel elements length, intervessel pit area, fiber lumen diameter, and fiber wall thickness, as well as a trial site $\times$ progeny interaction in vessel diameter and vessel wall thickness (Table 2).

\subsection{Climate Parameters at the Provenance Origins and Trial Sites}

Bioclimatic parameters of provenance origins and trial sites showed a clear cluster including GA and BA provenances (Figure 5). AS provenance is located at the periphery of the plot, indicating its distinct position and different climatic conditions in relation to the two other provenances. The trial sites are located in different positions in the plot. PE trial site is included in the same cluster as BA and GA provenances, indicating very similar climatic parameters. The first principal component of the PCA (PC1) explained $80.28 \%$ of the variation and was mainly connected to thermal conditions; more specifically it was positively correlated with mean temperature of the driest quarter (bio9) and mean temperature of the coldest quarter (bio 11). The second principal component of the PCA (PC2) explained $13.52 \%$ of the variation, was connected to precipitation, and, more specifically, it was correlated positively with annual precipitation (bio 12).

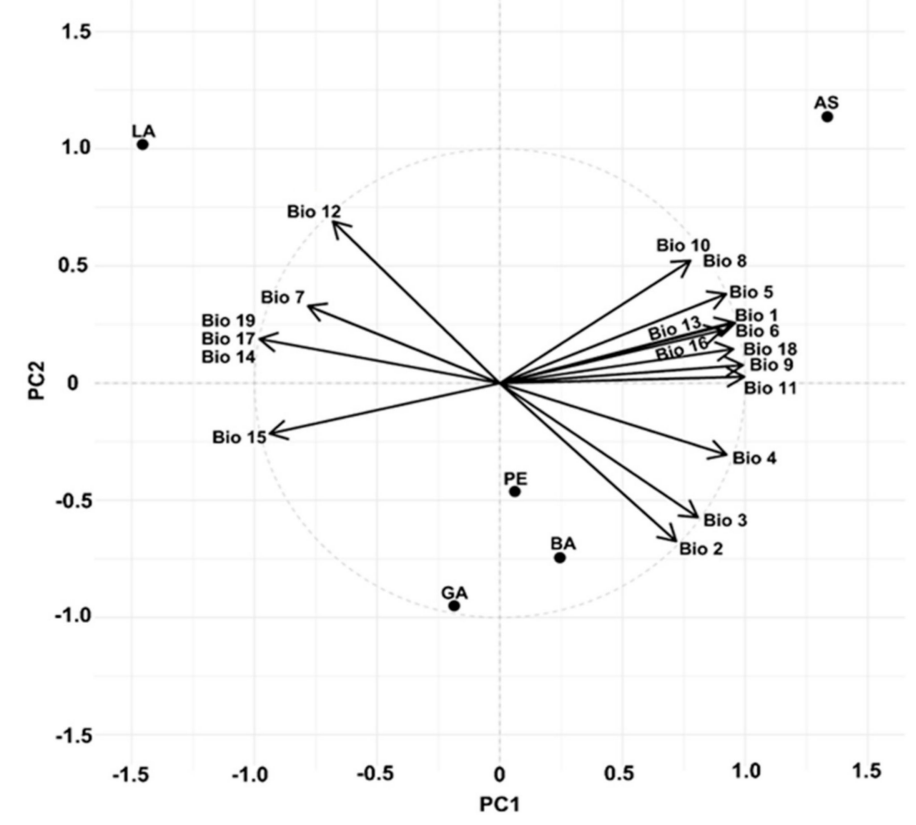

Figure 5. Principal component analysis of the climatic distance between sites of provenance origin (AS, $\mathrm{BA}$, and GA) and common gardens (LA and PE) based on the bioclimatic parameters.

\subsection{Transfer Functions}

Temperature, precipitation, and SPEI of the trial sites had an effect on stem height and diameter at breast height and on most wood features in B. riedelianum trees (Table 3). Differences in stem height and diameter at breast height were related to variation in precipitation and SPEI with the increase in stem height and diameter when trees were transferred to a wetter location. However, stem height and diameter decrease when the provenances were transferred to the trial site with more drought (Figure 6). 
Table 3. Regression analysis relating effects of mean temperature, precipitation and standardized precipitation evapotranspiration index (SPEI) on wood and growth features of 30-year-old Balfourodendron riedelianum trees. Standard error (SE).

\begin{tabular}{|c|c|c|c|c|c|c|c|c|}
\hline \multirow[t]{2}{*}{ • } & \multicolumn{2}{|c|}{ Mean Temperature } & \multicolumn{2}{|c|}{ Precipitation } & \multicolumn{2}{|c|}{$\begin{array}{c}\text { Precipitation } \times \text { Mean } \\
\text { Temperature }\end{array}$} & \multicolumn{2}{|c|}{ SPEI } \\
\hline & Estimate $\pm \mathrm{SE}$ & $p$ & Estimate $\pm \mathrm{SE}$ & $p$ & Estimate \pm SE & $p$ & Estimate $\pm \mathrm{SE}$ & $p$ \\
\hline Stem height & $0.47 \pm 0.52$ & 0.36 & $0.01 \pm<0.01$ & $<0.001$ & $-0.002 \pm<0.01$ & 0.58 & $-43.20 \pm 6.87$ & $<0.001$ \\
\hline Stem diameter at breast height & $0.57 \pm 0.60$ & 0.33 & $0.01 \pm<0.01$ & 0.03 & $0.001 \pm<0.01$ & 0.98 & $-24.50 \pm 7.88$ & 0.002 \\
\hline Wood density & $-0.01 \pm<0.01$ & 0.01 & $<0.001 \pm<0.01$ & 0.52 & $0.0001 \pm<0.01$ & 0.10 & $-0.09 \pm 0.10$ & 0.36 \\
\hline Potential hydraulic conductivity & $2.11 \pm 0.11$ & 0.44 & $0.08 \pm 0.02$ & 0.001 & $0.052 \pm 0.02$ & 0.02 & $-86.01 \pm 38.15$ & 0.03 \\
\hline Vessel diameter & $2.95 \pm 1.43$ & 0.04 & $0.03 \pm 0.01$ & 0.01 & $-0.005 \pm 0.01$ & 0.65 & $-90.04 \pm 17.93$ & $<0.0001$ \\
\hline Vessel wall thickness & $0.46 \pm 0.22$ & 0.04 & $-0.002 \pm<0.01$ & 0.19 & $-0.0008 \pm<0.01$ & 0.63 & $2.32 \pm 3.20$ & 0.47 \\
\hline Vessel density & $-3.22 \pm 3.36$ & 0.34 & $-0.05 \pm 0.03$ & 0.09 & $-0.043 \pm 0.03$ & 0.12 & $20.52 \pm 46.32$ & 0.66 \\
\hline Vessel element length & $-1.83 \pm 6.23$ & 0.77 & $0.11 \pm 0.05$ & 0.05 & $-0.034 \pm 0.05$ & 0.50 & $376.8 \pm 80.77$ & $<0.001$ \\
\hline Vessel grouping index & $-0.13 \pm 0.06$ & 0.03 & $<-0.01 \pm<0.01$ & 0.46 & $<0.001 \pm<0.01$ & 0.86 & $0.669 \pm 0.85$ & 0.43 \\
\hline Fiber length & $27.80 \pm 23.15$ & 0.23 & $0.53 \pm 0.20$ & 0.01 & $0.291 \pm 0.19$ & 0.13 & $-52.77 \pm 323.8$ & 0.87 \\
\hline Fiber diameter & $0.30 \pm 0.14$ & 0.03 & $<0.01 \pm<0.01$ & 0.48 & $-0.0008 \pm 0.001$ & 0.46 & $-0.212 \pm 1.90$ & 0.91 \\
\hline Fiber lumen diameter & $-0.16 \pm 0.90$ & 0.08 & $<-0.01 \pm<0.01$ & 0.22 & $0.002 \pm<0.01$ & 0.004 & $5.634 \pm 1.29$ & $<0.001$ \\
\hline Fiber wall thickness & $0.22 \pm 0.08$ & 0.008 & $<0.01 \pm<0.01$ & 0.82 & $-0.001 \pm<0.01$ & 0.005 & $-2.17 \pm 1.16$ & 0.06 \\
\hline Ray height & $13.17 \pm 6.10$ & 0.03 & $0.02 \pm 0.05$ & 0.62 & $-0.04 \pm 0.05$ & 0.35 & $-97.53 \pm 82.21$ & 0.24 \\
\hline Ray width & $1.45 \pm 0.75$ & 0.06 & $<-0.01 \pm 0.66$ & 0.54 & $-0.006 \pm 0.006$ & 0.29 & $4.08 \pm 10.20$ & 0.69 \\
\hline Ray density & $-0.46 \pm 0.14$ & 0.001 & $<-0.01 \pm<0.01$ & $<0.001$ & $0.002 \pm 0.001$ & 0.02 & $15.19 \pm 2.05$ & $<0.001$ \\
\hline Vessel fraction & $1.64 \pm 0.89$ & 0.07 & $0.01 \pm<0.01$ & 0.11 & $-0.005 \pm 0.007$ & 0.43 & $-17.10 \pm 12.3$ & 0.17 \\
\hline Fiber fraction & $-1.01 \pm 1.29$ & 0.43 & $<0.01 \pm 0.01$ & 0.76 & $0.01 \pm 0.10$ & 0.32 & $-7.40 \pm 17.06$ & 0.66 \\
\hline Parenchyma fraction & $-0.56 \pm 0.70$ & 0.42 & $-0.01 \pm<0.01$ & 0.02 & $-0.003 \pm 0.005$ & 0.52 & $22.33 \pm 9.19$ & 0.01 \\
\hline
\end{tabular}




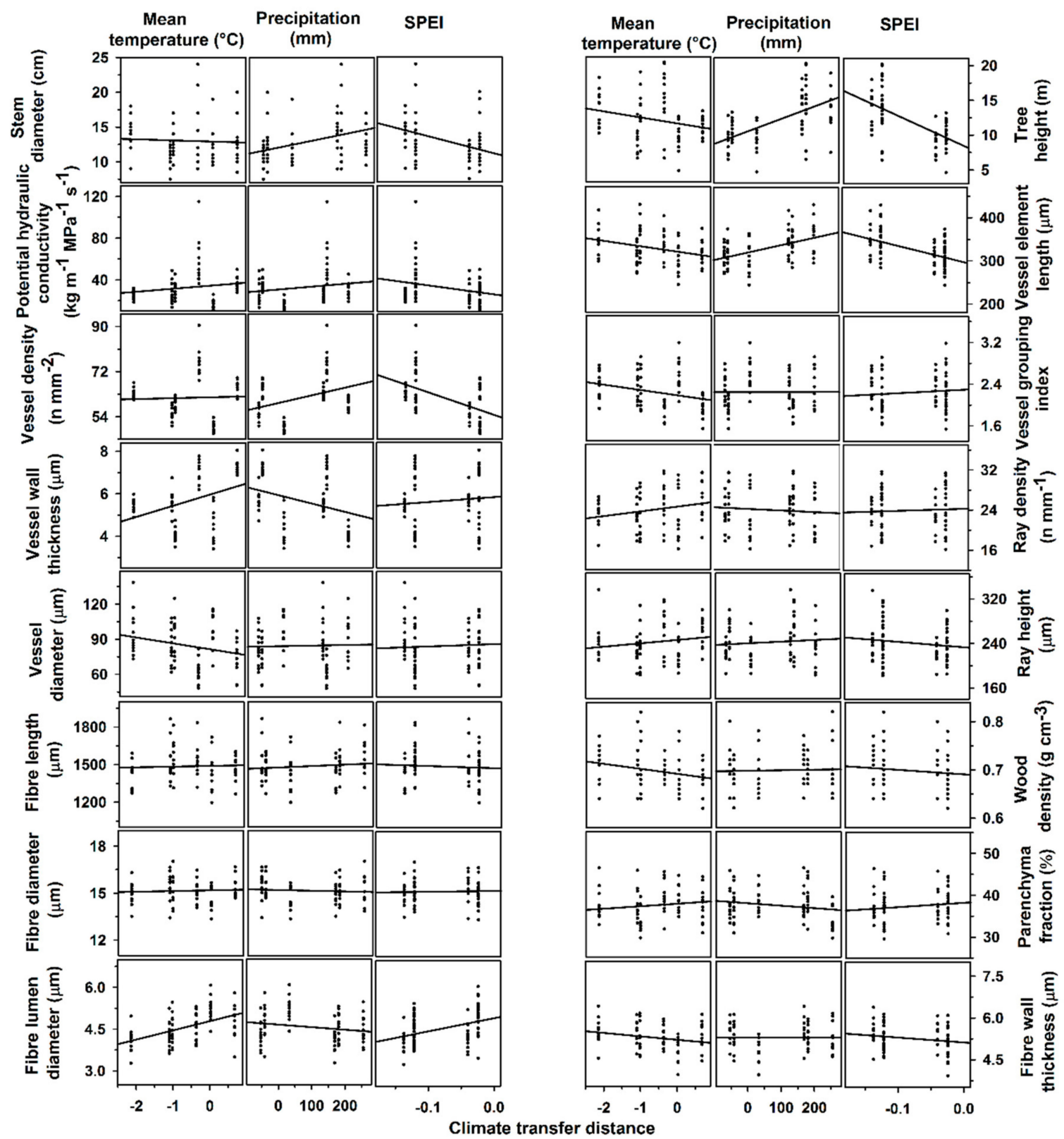

Figure 6. Growth and wood features response of Balfourodendron riedelianum trees to climatic transfer distance.

The temperature of the trial sites had greater influence on wood features. Trees transferred to a warmer trial site had lower wood density, larger vessel diameter, thicker vessel wall, lower vessel grouping index, larger fiber diameter, lower fiber wall thickness, and higher height and ray density than trees transferred to a cooler trial site (Table 3; Figure 6).

Precipitation and SPEI also had an effect on vessel diameter, potential hydraulic conductivity and length of vessel elements. The trees transferred to a wetter trial site and with less SPEI had a larger vessel diameter, higher potential hydraulic conductivity, longer vessel elements, lower ray density, and lower parenchyma fraction than trees transferred to a drier trial site. The fiber lumen diameter was affected only by the SPEI, with trees transferred to a drier trial site having a larger fiber lumen diameter. Moreover, there was an interaction between precipitation and temperature in the potential hydraulic conductivity, ray density, fiber lumen diameter, and fiber wall thickness (Figure 6). 


\section{Discussion}

This study investigated the intraspecific variation in wood features and tree growth of B. riedelianum trees originating from three populations and grown in two common garden experiments in São Paulo State, Brazil. The results show that tree growth, determined by stem height and diameter, was mostly influenced by the environment at the trial sites, specifically precipitation and SPEI, being promoted by wet conditions. Wood features vary among populations and are strongly influenced by the temperature of trial sites.

\subsection{Genetic Difference between Populations}

We raised the hypothesis that intraspecific variation in the wood features of B. riedelianum trees would be related to the climatic of populations origin site. We expected that populations from drier and warmer sites, with lower precipitation, would have wood characterized by higher water transport safety than trees from cooler sites with higher precipitation. Indeed, trees from Bauru, the site with lower annual precipitation and higher temperature, had narrower vessels and thinner walls, more clustered and denser, and occupying a larger fraction of wood than trees from other populations. Together, these anatomical features provide greater safety for water transport under higher negative tensions in drier environments [16,38]. However, unlike our expectation, trees from Alvorada do Sul, the site with higher annual precipitation than other provenances showed wood with water safety similar to that in trees from Bauru. We observed wood anatomical features with greater efficiency in water transport in trees from Gália, the site with intermediate precipitation between provenances.

We found a lower potential hydraulic conductivity, narrow vessels, with thin walls, in higher density and more clustered, with smaller intervessel pits and narrow openings, rays in higher density and higher parenchyma fraction (axial parenchyma + rays), features that together indicate greater water transport safety in trees from Alvorada do Sul. This region is characterized by high rainfall, fertile soils, low winter temperatures, and being prone to frost [28]. In general, narrow vessels are advantageous in sites with low temperatures to avoid freeze-induced cavitation, as well as to minimize the impacts of drought-induced cavitation [46]. According to Fisher et al. [5] and Schreiber et al. [6], the selection of narrow vessels may be an adaptation in populations that experience freezing periods that minimize the effects caused by frost induced cavitation, thus maintaining the xylem functional for the next growing season. Our findings, therefore, suggest that the formation of wood with high hydraulic safety in trees from Alvorada do Sul could reflect the low temperatures experienced at the origin site. However, experimental studies are necessary to confirm this statement.

\subsection{Phenotypic Plasticity of Tree Growth and Wood Formation}

In general, our trees responded to the increase in water availability through the formation of wood with a higher water transport efficiency. Regardless of origin, trees grown in a wetter environment (Luís Antônio) had wider vessels, with thicker walls, less clustered, with larger intervessel pits and wider openings, longer vessel elements, fibers with narrower lumen and thicker walls, less frequent rays and smaller fraction of parenchyma (axial parenchyma + rays). The increase in vessel diameter also had a positive effect on potential hydraulic conductivity. Our results showed that the vessels are the cells with the highest degree of plasticity in B. riedelianum, with variations in diameter, wall thickness, grouping, and size of intervessel pits. Vessels are responsible for long-distance water conduction in plants, performing a central role in hydraulic efficiency and safety [16]. Variations in vessel dimensions could represent a key trait for the adaptation or acclimation to changes in environmental conditions, such as increasing of temperatures and drought events, thus ensuring growth and survival of this species within its natural distribution range.

The plastic responses observed in wood of mature B. riedelianum trees in the wetter trial site reflect greater efficiency in conducting water and mechanical support on vessel walls. In this trial site, the formation of larger vessels provides low resistance to water flow and increases water transport 
ability $[16,18]$. The thickening of vessel walls makes larger vessels less prone to mechanical damage, such as micro-fractures and implosion of their walls [16]. Micro-fractures in the vessel wall may trigger the heterogeneous nucleation of gas particles between the cell walls or intercellular spaces, initiating the embolism process [38,47]. Large, thick-walled vessels also have larger intervessel pits with wider openings. These latter are potentially more efficient in conducting water but decrease the mechanical reinforcement of vessel cell walls [11,48]. In addition, intervessel pits with large openings could decrease support to the pit membrane during stretching [49]. Thus, the formation of fibers with narrower lumen and thicker walls found in B. riedelianum trees grown in the wetter trial site could compensate for potential cell wall weakening. Therefore, wide thicker-walled vessels immersed in a denser fiber matrix may confer greater mechanical strength to support larger intervessel pits and with wider openings in the wood.

We found plasticity in the size of vessel elements. In vessels, the length is determined by the size of initial fusiforms of the vascular cambium [50], and the diameter is linked to cell expansion. Variation in water availability to vascular cambium has an effect on the elongation of the initial fusiforms [51] and cellular expansion [52]. Therefore, the higher water availability in Luís Antônio may have favored the formation of longer and wider vessels. Similarly, the lower precipitation in Pederneiras may have been a limiting factor to elongation of the initial fusiform of the vascular cambium and cell expansion, thus resulting in the formation of shorter vessel elements and narrower vessels.

When testing the responses of the wood of B. reidelianum to variations in temperature, precipitation and SPEI among trial sites using transfer functions, we found that temperature had a greater effect on the anatomical features of vessels, fibers and rays. In general, the wood showed a greater capacity to water transport and vulnerability to mechanical damage, with larger vessels, less clustered and with thicker walls and longer fibers, wider and thinner walls in warmer environments. In the context of ongoing global changes, plants will experience warmer temperatures, often associated with less precipitation. The formation of wider vessels makes the wood more prone to drought-induced embolism, leading to hydraulic failure and even tree death [53]. Our results also indicate that taller rays and higher density occur in warmer environments. From the functional perspective, taller rays and higher density associated with larger vessels would be an important requirement to maintain hydraulic conductance in the stem, as well as hydraulic recovery through vessel refilling mechanisms [20,54].

Our results also indicate that wood density responds to an increase in temperature, with less dense wood occurring in warmer environments. The lower density may result from the combination of wider elements, vessels, and fibers, with thinner walls. Less dense wood leads to a decrease in the mechanical strength of the stem [55], making it more fragile and prone to breakage caused by animals or falling debris [56]. The decrease in wood density makes plants less resistant to damage caused by herbivores and pathogen attack, which can decrease their growth, life-span, and biomass allocation [57]. Therefore, our results suggest that an increase in temperature may stimulate $B$. riedelianum to form wood more prone to embolism, with lower mechanical resistance and higher susceptibility to pathogen attack.

The growth in stem height and diameter was sensitive to changes in the environmental conditions of the trial sites. Regardless of provenance, all trees responded similarly in both common garden experiments, with increased growth in stem height and diameter in the wetter trial site. In addition, the result of the transfer function on stem height and diameter growth demonstrates that tree growth benefits from an increase in precipitation and responds negatively to higher SPEI. Considering the climate predictions indicating 25\% increases in precipitation across the natural range of B. riedelianum, a region that mainly covers southern and south-eastern Brazil [24], we may expect a positive impact on tree growth in a future scenario. However, the possible benefits of an increase in precipitation should be carefully examined. Firstly, possible changes in rainfall intensity, duration, and distribution throughout the year should be taken into account. Secondly, south and south-eastern Brazil is already exploited for crop production, and potential new areas are awaiting future agricultural expansion and development in the next decades, which will make the natural range of the studied species more prone to deforestation. At the same time, an important warming is predicted in South America [24], making it 
difficult to predict the growth responses of trees under complex climate change scenarios. Under these conditions, plastic responses in the growth of $B$. riedelianum could be essential to guarantee persistence of the species in the drier sites.

\section{Conclusions}

In this study, we investigated the intraspecific variation in wood features and tree growth of three populations of Balfourodendron riedelianum growing in two common garden experiments and evaluated the effect of climate at the origin sites through transfer functions. We observed that phenotypic variability in wood features results from a clear genetic differentiation between populations. We found that both genotype and environment have an effect on wood features, while variability in tree growth is mostly determined by the environment. Based on the wide variability in wood features and tree growth, B. riedelianum could be able to adjust growth and hydraulic traits to withstand the changes in temperature and precipitation predicted by the climatic models in the next decades, thus ensuring the survival of this species under warmer scenarios.

Supplementary Materials: The following are available online at http://www.mdpi.com/1999-4907/11/9/905/s1, Table S1: Height of stem, diameter at breast height of the stem, wood density, potential hydraulic conductivity and wood quantitative anatomical features of 30-year-old Balfourodendron riedelianum trees from three provenance (AS, BA and GA) grown in Luís Antônio and Pederneiras common garden experiments. AS = Alvorada do Sul; $\mathrm{BA}=$ Bauru; $\mathrm{GA}=$ Gália. The values are shown as mean \pm standard deviation (minimum and maximum values).

Author Contributions: J.R.d.S., E.L.L. and C.R.M. designed the study; J.R.d.S., C.R.M, S.K. and S.R. analysed the data; J.R.d.S., E.L.L., S.K., S.R. and C.R.M. wrote the manuscript; J.R.d.S. and S.K. were corresponding authors. All authors have read and agreed to the published version of the manuscript.

Funding: This research was funded by Fundação de Amparo à Pesquisa do Estado de São Paulo (FAPESP, Proc. 2015/14954-1) for financial resources to C.R. Marcati; We thank Coordenação de Aperfeiçoamento de Pessoal de Nivel Superior-Brasil (CAPES) for the scholarship funding to the first author and, CAPES-Print (Finance Code $462)$ to the second author.

Acknowledgments: We thank Instituto Florestal de São Paulo for authorization to collect in the study areas, and to Scientific Researchers: Antonio Carlos Scatena Zanatto and José Arimatéia Rabelo Machado for their support in the field. The authors thank A. Garside for editing the English text.

Conflicts of Interest: The authors declare no conflict of interest.

\section{References}

1. Corcuera, L.; Cochard, H.; Gil-Pelegrin, E.; Notivol, E. Phenotypic plasticity in mesic populations of Pinus pinaster improves resistance to xylem embolism (P50) under severe drought. Trees Struct. Funct. 2011, 25, 1033-1042. [CrossRef]

2. Anderegg, W.R.L. Spatial and temporal variation in plant hydraulic traits and their relevance for climate change impacts on vegetation. New Phytol. 2015, 205, 1008-1014. [CrossRef] [PubMed]

3. Wortemann, R.; Herbette, S.; Barigah, T.S.; Fumanal, B.; Alia, R.; Ducousso, A.; Gomory, D.; Roeckel-Drevet, P.; Cochard, H. Genotypic variability and phenotypic plasticity of cavitation resistance in Fagus sylvatica L. across Europe. Tree Physiol. 2011, 31, 1175-1182. [CrossRef] [PubMed]

4. López, R.; Heredia, U.L.; Collada, C.; Cano, F.J.; Emerson, B.C.; Cochard, H.; Gil, L. Vulnerability to cavitation, hydraulic efficiency, growth and survival in an insular pine (Pinus canariensis). Ann. Bot. 2013, 111, 1167-1179. [CrossRef] [PubMed]

5. Fisher, J.B.; Goldstein, G.; Jones, T.J.; Cordell, S. Wood vessel diameter is related to elevation and genotype in the Hawaiian tree Metrosideros polymorpha (Myrtaceae). Am. J. Bot. 2007, 94, 709-715. [CrossRef] [PubMed]

6. Schreiber, S.G.; Hacke, U.G.; Hamann, A. Variation of xylem vessel diameters across a climate gradient: Insight from a reciprocal transplant experiment with a widespread boreal tree. Funct. Ecol. 2015, 29, 1392-1401. [CrossRef]

7. Hajek, P.; Kurjak, D.; von Wühlisch, G.; Delzon, S.; Schuldt, B. Intraspecific variation in wood anatomical, hydraulic, and foliar traits in ten European beech provenances differing in growth yield. Front. Plant Sci. 2016, 7, 1-14. [CrossRef] 
8. Eilmann, B.; Vries, S.M.G.D.; Ouden, J.D.; Mohren, G.M.J.; Sauren, P.; Sass-Klaassen, U. Origin matters! Difference in drought tolerance and productivity of coastal Douglas-fir (Pseudotsuga menziesii (Mirb.)) provenances. Forest Ecol. Manag. 2013, 302, 133-143. [CrossRef]

9. O'Brien, E.K.; Mazanec, R.A.; Krauss, S.L. Provenance variation of ecologically important traits of forest trees: Implications for restoration. J. Appl. Ecol. 2007, 44, 583-593. [CrossRef]

10. Baas, P.; Ewers, F.W.; Davis, S.D.; Wheeler, E.A. Evolution of xylem physiology. In The Evolution of Plant Physiology; Hemley, A.R., Poole, I., Eds.; Elsevier Academic Press: Amsterdam, The Netherlands, 2004; pp. 273-295.

11. Carlquist, S. How wood evolves: A new synthesis. Botany 2012, 90, 901-940. [CrossRef]

12. Baas, P.; Carlquist, S. A comparison of the ecological wood anatomy of the floras of Southern California and Israel. IAWA Bull. 1985, 6, 349-353. [CrossRef]

13. Barajas-Morales, J. Wood structural differences between trees of two Tropical Forests in Mexico. IAWA J. 1985, 6, 355-364. [CrossRef]

14. Lindorf, H. Eco-anatomical wood features of species from a very dry tropical forest. IAWA J. 1994, 15, 361-376. [CrossRef]

15. Carlquist, S.; Hoekman, D.A. Ecological wood anatomy of the woody-Southern Californian flora. IAWA Bull. 1985, 6, 319-347. [CrossRef]

16. Hacke, U.G.; Sperry, J.S. Functional and ecological xylem anatomy. Perspect. Plant Ecol. Evol. Syst. 2001, 4, 97-115. [CrossRef]

17. Carlquist, S. Ecological factors in wood evolution: A floristic approach. Am. J. Bot. 1977, 64, 887-895. [CrossRef]

18. Tyree, M.T.; Davis, S.D.; Cochard, H. Biophysical perspectives of xylem evolution: Is there a tradeoff of hydraulic efficiency for vulnerability to dysfunction? IAWA J. 1994, 15, 335-360. [CrossRef]

19. Morris, H.; Gillingham, M.A.F.; Plavcová, L.; Gleason, S.M.; Olson, M.E.; Coomes, D.A.; Fichtler, E.; Klepsch, M.M.; Martínez-Cabrera, H.I.; McGlinn, D.J.; et al. Vessel diameter is related to amount and spatial arrangement of axial parenchyma in woody angiosperms. Plant. Cell Environ. 2018, 41, 245-260. [CrossRef]

20. Salleo, S.; Lo Gullo, M.A.; Trifiló, P.; Nardini, A. New evidence for a role of vessel-associated cells and phloem in the rapid xylem refilling of cavitated stems of Laurus nobilis L. Plant Cell Environ. 2004, 27, 1065-1076. [CrossRef]

21. Borchert, R.; Pockman, W.T. Water storage capacitance and xylem tension in isolated branches of temperate and tropical trees. Tree Physiol. 2005, 25, 457-466. [CrossRef]

22. Poorter, L.; McDonald, I.; Alarcón, A.; Fichtler, E.; Licona, J.C.; Peña-Claros, M.; Sterck, F.; Villegas, Z.; Sass-Klaassen, U. The importance of wood traits and hydraulic conductance for the performance and life history strategies of 42 rainforest tree species. New Phytol. 2010, 185, 481-492. [CrossRef] [PubMed]

23. Chave, J.; Coomes, D.; Jansen, S.; Lewis, S.L.; Swenson, N.G.; Zanne, A.E. Towards a worldwide wood economics spectrum. Ecol. Lett. 2009, 12, 351-366. [CrossRef] [PubMed]

24. Magrin, G.; Marengo, J.; Boulanger, J.; Buckeridge, M.; Castellanos, E.; Poveda, G.; Scarano, F.R.; Vicuña, S. Central and South America. In Climate Change 2014: Impacts, Adaptation, and Vulnerability. Part B: Regional Aspects. Contribution of Working Group II to the Fifth Assessment Report of the Intergovernmental Panel on Climate Change; Barros, V.R., Field, C.B., Dokken, D.J., Mastrandrea, M.D., Mach, K.J., Bilir, T.E., Chatterjee, M., Ebi, K.L., Estrada, Y.O., Genova, R.C., et al., Eds.; Cambridge University Press: Cambridge, UK; New York, NY, USA, 2014; pp. 1499-1566.

25. Carvalho, P. Espécies Arbóreas Brasileiras; Colombo: Embrapa Floresta, PR, Brazil, 2003.

26. Araújo, D.; Sebbenn, A.M.; Zanatto, A.C.S.; Zanata, M.; Morais, E.; de Moraes, M.L.T.; Freitas, M.L.M. Variação genética para caracteres silviculturais em progênies de polinização aberta de Astronium graveolens Jacq. (Anacardiaceae). Cerne 2014, 20, 61-68. [CrossRef]

27. Kubota, T.Y.; de Moraes, M.A.; da Silva, E.C.B.; Pupin, S.; Aguiar, A.V.; de Moraes, M.L.T.; Freitas, M.L.M.; Sato, A.S.; Machado, J.A.R.; Sebbenn, A.M. Variabilidade genética para caracteres silviculturais em progênies de polinização aberta de Balfourodendron riedelianum (Engler). Sci. For. 2015, 43, 407-415.

28. Bhering, S.B.; Santos, H.G.; Manzatto, C.V.; Bognola, I.; Carvalho, A.P.; Potter, O.; Aglio, M.L.D.; Silva, J.S.; Chaffin, C.E.; Carvalho Junior, W. Mapa do Solo do Estado do Paraná; Embrapa Solos: Rio de Janeiro, Brazil, 2007.

29. ESALQ-USP. Parcelas Permanentes em 40 ha de Florestas do Estado de São Paulo: Uma Experiência Multidisciplinar; ESALQ-USP: Piracicaba, Brazil, 2006. 
30. Gurgel-Garrido, L.M.A.; Siqueira, A.C.M.F.; Cruz, S.F.; Romanelli, R.C.; Ettori, L.C.; Crestana, C.S.M.; Silva, A.A.; Morais, E.; Zanatto, A.C.S.; Sato, A.S. Programa de melhoramento genético florestal. IF Série Regist. 1997, 18, 1-53.

31. Johansen, D.A. Plant Microtechnique; McGraw-Hill Book Company: New York, NY, USA, 1940; 528p.

32. Bukatsch, F. Bemerkungen zur doppelfärbung astrablau-safranin. Mikrokosmost 1972, 61, 33-36.

33. Roeser, K. Die Nadel der Schwarzkiefer-Massenprodukt und Kunstwerk der Natur. Mikrokosmos 1972, 61, 33-36.

34. Franklin, G. Preparation of thin sections of synthetic resins and wood-resins composites, and a new macerating method for wood. Nature 1945, 155, 51. [CrossRef]

35. Kraus, J.E.; Arduin, M. Manual Básico de Métodos em Morfologia Vegetal; EDUR: Seropédica, Rio de Janeiro, Brazil, 1997; 198p.

36. IAWA Committee. List of microscopic features for hardwood identification. IAWA Bull. 1989, 10, $220-332$.

37. Scholz, A.; Klepsch, M.; Karimi, Z.; Jansen, S. How to quantify conduits in wood? Front. Plant Sci. 2013, 4, 56. [CrossRef]

38. Tyree, M.; Zimmermann, M. Xylem Structure and the Ascent of Sap; Springer-Verlag: Berlin/Heidelberg, Germany, 2002.

39. Carlquist, S. Vessel grouping in dicotyledon wood: Significance and relationship to imperforate tracheary elements. Aliso 1984, 10, 505-525. [CrossRef]

40. Williamson, G.B.; Wiemann, M.C. Measuring wood specific gravity ... Correctly. Am. J. Bot. 2010, 97, 519-524. [CrossRef] [PubMed]

41. Fick, S.E.; Hijmans, R.J. WorldClim 2: New 1-km spatial resolution climate surfaces for global land areas. Int. J. Climatol. 2017, 37, 4302-4315. [CrossRef]

42. Vicente-Serrano, S.M.; Beguería, S.; López-Moreno, J.I. A multiscalar drought index sensitive to global warming: The standardized precipitation evapotranspiration index. J. Clim. 2010, 23, 1696-1718. [CrossRef]

43. Beguería, S.; Vicente-Serrano, S.M.; Beguería, M.S. Package 'SPEI'. 2017. Available online: https://cran.rproject.org/web/packages/SPEI/SPEI.pdf (accessed on 12 April 2020).

44. R Core Team. R: A Language and Environment for Statistical Computing; R Foundation for Statistical Computing: Vienna, Austria, 2019; Available online: http://www.R-project.org/ (accessed on 21 March 2020).

45. O'Donnell, M.S.; Ignizio, D.A. Bioclimatic predictors for supporting ecological applications in the conterminous United States. US Geol. Surv. Data Ser. 2012, 691, 10.

46. Pittermann, J.; Sperry, J. Tracheid diameter is the key trait determining the extent of freezing-induced embolism in conifers. Tree Physiol. 2003, 23, 907-914. [CrossRef]

47. Lens, F.; Tixier, A.; Cochard, H.; Sperry, J.S.; Jansen, S.; Herbette, S. Embolism resistance as a key mechanism to understand adaptive plant strategies. Curr. Opin. Plant Biol. 2013, 16, 287-292. [CrossRef] [PubMed]

48. Hacke, U.G.; Sperry, J.S.; Pockman, W.T.; Davis, S.D.; McCulloh, K.A. Trends in wood density and structure are linked to prevention of xylem implosion by negative pressure. Oecologia 2001, 126, 457-461. [CrossRef]

49. Jansen, S.; Choat, B.; Pletsers, A. Morphological variation of intervessel pit membranes and implications to xylem function in angiosperms. Am. J. Bot. 2009, 96, 409-419. [CrossRef]

50. Carlquist, S. Comparative Wood Anatomy: Systematic, Ecological, and Evolutionary Aspects of Dicotyledon Wood; Springer: Berlin/Heidelberg, Germany, 2001; ISBN 9783642640711.

51. Lim, D.O.; Soh, W.Y. Cambial development and tracheid length of dwarf pines (Pinus densiflora and P. thunbergii). IAWA J. 1997, 18, 301-310. [CrossRef]

52. Abe, H.; Nakai, T.; Utsumi, Y.; Kagawa, A. Temporal water deficit and wood formation in Cryptomeria japonica. Tree Physiol. 2003, 23, 859-863. [CrossRef] [PubMed]

53. Hacke, U.G.; Sperry, J.S.; Wheeler, J.K.; Castro, L. Scaling of angiosperm xylem structure with safety and efficiency. Tree Physiol. 2006, 26, 689-701. [CrossRef] [PubMed]

54. Hölttä, T.; Mencuccini, M.; Nikinmaa, E. Linking phloem function to structure: Analysis with a coupled xylem-phloem transport model. J. Theor. Biol. 2009, 259, 325-337. [CrossRef] [PubMed]

55. Niklas, K.J. Plant Biomechanics: An Engineering Approach to Plant Form and Function; University of Chicago Press: Chicago, IL, USA, 1992. 
56. Poorter, L. The relationships of wood-, gas- and water fractions of tree stems to performance and life history variation in tropical trees. Ann. Bot. 2008, 102, 367-375. [CrossRef]

57. Augspurger, C.K.; Kelly, C.K. Pathogen mortality of tropical tree seedlings: Experimental studies of the effects of dispersal distance, seedling density, and light conditions. Oecologia 1984, 61, 211-217. [CrossRef]

(C) 2020 by the authors. Licensee MDPI, Basel, Switzerland. This article is an open access article distributed under the terms and conditions of the Creative Commons Attribution (CC BY) license (http://creativecommons.org/licenses/by/4.0/). 